〔30〕 カチオン重合の生長反応に関する研究

第 3 報 四塩化スズによるスチレンの重合

(1961 年 7 月 24 日受理)

加納夏樹* ・東村敏延* ・岡村誠三*

\begin{abstract}
要 旨 スチレン一四塩化スズ系を例にとり, カチオン重合の定常状態に拄ける生艮反応の速度定数 $\left(k_{p}\right)$ の一般的な測定法を述へた。第 1 報1，第 2 報ではヨウドを開始剤とするカチオン重合系について検郡し， 生長反応の速度定数は重合系の质電率が大きいはど大きいことが明らかになった。本報では，開始剈として四 塩化スズおよびヨウドを用い，二塩化エチレン中でスチレンを重合し，その結果対アニオンが強い Lewis 酸 から生じたものであるほど $k_{p}$ が大きいことが明らかになった。
\end{abstract}

\section{1. 粕言}

重合機構を検討するためには，その素反応の反応速度 定数を測定することが望ましい。しかしカチオン重合の 場合, 特殊な采について特殊な仮定のもとに行なった二 三の報告8) しか得られていない。かれわれは前報1),2) に おいて定常状態における $k_{p}$ の測定法について検討し, ヨ ウドを開始剤とする系について報告した。しかし前報で 述へた方法はヨウドメトリー, 可視吸収スペクトルなど, ヨウド特有の定量法を利用したものであり，したがって 開始剤としてヨウドを用いるカチオン重合采にしか適用 できなかった。ここではさらに一般的な系, すなわちモ ノマーと開始剤の間に $\pi$-complex が存在し，その濃度 が紫外吸収スペクトルによって定量可能な系の $k_{p}$ の測 定法について述へる。この方法によって,スチレンー四塩 化スズ-二塩化ェチレン采の $k_{p}$ を測定し，あわせて前報 で述ベた方法によって，スチレンーヨウド-二塩化エチレ

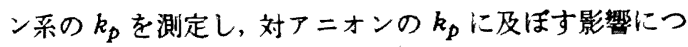
いて検討する。

\section{2. $k_{p}$ の 测定 法}

前報1),2) で述べたごとく, $k_{p}$ を求めるため次の 2 点を 考えた。

a) モノマー(M)と開始剂(C)との間に $\pi$-complex $(\mathrm{M} \cdot \mathrm{C})$ が存在し次の関倸にある゙。

$$
\mathrm{M}+\mathrm{C} \rightleftarrows \mathrm{M} \cdot \mathrm{C} \text { 平衡定数 } K_{M}
$$

b) 定常状態の初期においては次の関係が成立する。

$$
[\mathrm{C}]_{\text {total }}=[\mathrm{C}]_{\text {free }}+[\mathrm{M} \cdot \mathrm{C}]+\left[\mathrm{M}^{*}\right]
$$

M*：活性末端

上記 a) およびb) の仮定は妥当であり，(2) 式は従来 の取扱を一般化したものであることは前報において述べ た。(1), (2) 式の関係を考慮し, また活性末端の自己停止 反応を仮定すると，それぞれの開始反応に対応して次に 述べる諸式を導くことができる。それを適用す!ると，

\footnotetext{
* 京都大学工学部高分子化学教室(京都市左京区吉田泉殿町)
}

[M*]が定量できる系のみならず, [M·C] が定量できる系 においてを $k_{p}$ を計算することができる。

\section{1 [M.C] が测定可能な場合}

活性末端に関して定常状態を仮定し，(1)，(2)式および $d\left[\mathrm{M}^{*}\right] / d t=0$ から $[\mathrm{C}]_{\mathrm{free}},\left[\mathrm{M}^{*}\right]$ を消去する。

\section{1 .1 遊離の開始用が重合を開始する場合}

素反応

$\begin{array}{ll}\text { complex 生成反応 } & \mathrm{C}_{\mathrm{free}}+\mathrm{M} \underset{k_{i}}{\stackrel{K_{M}}{\longrightarrow}} \mathrm{M} \cdot \mathrm{C} \\ \text { 開始反長反応 } & \mathrm{C}_{\mathrm{free}}+\mathrm{M} \underset{{ }_{k p}}{\longrightarrow} \mathrm{M}^{*} \\ \text { 停止反応 } & \mathrm{M}_{n}{ }^{*}+\mathrm{M} \stackrel{{ }_{k t}^{\longrightarrow}}{\longrightarrow} \mathrm{M}_{n+1}{ }^{*} \\ & \mathrm{M}_{n}{ }^{*} \stackrel{\stackrel{k}{\longrightarrow}}{\longrightarrow} \mathrm{P}_{n}\end{array}$

上記の素反応に対応して次の関係式を得た。

$$
\begin{gathered}
\frac{[\mathrm{C}]_{\text {total }}}{[\mathrm{M} \cdot \mathrm{C}]}=\frac{1}{K_{M} \cdot[\mathrm{M}]}+\frac{k_{i}}{k_{t}} \cdot \frac{1}{K_{M}}+1 \\
R_{p}=\frac{k_{p} \cdot\left(k_{i} / k_{t}\right)\left(1 / K_{M}\right)[\mathrm{M}][\mathrm{C}]_{\text {total }}}{\frac{1}{K_{M}[\mathrm{M}]}+\frac{k_{i}}{k_{t}} \cdot \frac{1}{K_{M}}+1}
\end{gathered}
$$

\section{1 .2 モノマーと開始䬉間の complex が重合を開 始する場合}

素反応

$$
\begin{aligned}
& \text { complex 生成反応 } \quad \mathrm{C}_{\text {free }}+\mathrm{M} \underset{k_{i}}{\stackrel{K_{M}}{\rightleftarrows}} \mathrm{M} \cdot \mathrm{C} \\
& \mathrm{M} \cdot \mathrm{C} \stackrel{k_{i}}{\longrightarrow} \mathrm{M}^{*}
\end{aligned}
$$

上記の素反応に対応して次の関倸式を得た。ただし生 長反忘, 停止反応は省略した。

$$
\begin{aligned}
& \frac{[\mathrm{C}]_{\text {total }}}{[\mathrm{M} \cdot \mathrm{C}]}=\frac{1}{K_{M} \cdot[\mathrm{M}]}+\frac{k_{i}}{k_{t}}+1 \\
& R_{p}=\frac{k_{p}\left(k_{i} / k_{t}\right) \cdot[\mathrm{M}][\mathrm{C}]_{\text {total }}}{1} \\
& K_{M}[\mathrm{M}]
\end{aligned}
$$


2.1.3 スチレン-四塩化ススー二塩化ェチレン系に Pleschが与えた次の素反応を仮定した場合

素反応 ${ }^{8 a)}$

complex 生成反応 $\mathrm{C}_{\mathrm{free}}+\mathrm{M} \stackrel{K_{M}}{\rightleftarrows} \mathrm{M} \cdot \mathrm{C}$ $\mathrm{C}_{\text {free }}+\mathrm{A} \stackrel{K_{A}}{\rightleftarrows} \mathrm{A} \cdot \mathrm{C}(\mathrm{A}$ 洪触媒 $)$

開始反応 $\mathrm{A} \cdot \mathrm{C}+\mathrm{M} \stackrel{k_{i}}{\longrightarrow} \mathrm{M}^{*}$

生長反応 $\mathrm{M}_{n}{ }^{*}+\mathrm{M} \stackrel{k p}{\longrightarrow} \mathrm{M}_{n+1}$ *

停止反応 $\mathrm{M}_{n}^{*} \stackrel{k t}{\longrightarrow} \mathrm{P}_{n}+\mathrm{A} \cdot \mathrm{C}$

上記の素反応に対応して次の関倸が得られる。

$$
\begin{gathered}
\frac{[\mathrm{C}]_{\text {total }}}{[\mathrm{M} \cdot \mathrm{C}]}=\left(\frac{1}{K_{M}}+\frac{K_{A}[\mathrm{~A}]}{K_{M}}\right) \frac{1}{[\mathrm{M}]} \\
\quad+\frac{k_{i}}{k_{t}} \cdot \frac{K_{A}[\mathrm{~A}]}{K_{M}}+1 \\
R_{p}=\frac{k_{p} \frac{k_{i}}{k_{t}} \cdot \frac{K_{A}[\mathrm{~A}]}{K_{M}} \cdot[\mathrm{M}][\mathrm{C}]_{\text {total }}}{\left(\frac{1}{K_{M}}+\frac{K_{A}[\mathrm{~A}]}{K_{M}}\right) \frac{1}{[\mathrm{M}]}+{ }^{k_{i}} \frac{K_{A}[\mathrm{~A}]}{k_{M}}+1}
\end{gathered}
$$

\section{$2.2\left[\mathrm{M}^{*}\right]$ が測定可能な場合}

これにつけては前報で述べたので，その結果のみを記 す。

\section{2 .1 遊離の触媒が重合を開始する場合}

$$
\frac{[\mathrm{C}]_{\text {total }}}{[\chi]}=1+\frac{k_{i}}{k_{l}} \cdot \frac{[\mathrm{M}][\chi]^{n-1}}{\left(1+K_{M}[\mathrm{M}]\right)^{n}}
$$

ただし $[\chi]=[\mathrm{C}]_{\text {total }}-\left[\mathrm{M}^{*}\right]$

(ただし， $n$ は開始反応における開始剤の反応次数)

2.2 .2 モノマーと開始郕間の complex が重合を開 始する場合

$$
\begin{aligned}
& \frac{[\mathrm{C}]_{\text {total }}}{[\chi]}=1+\left(\frac{k_{i}}{k_{t}} \cdot K . M\right) \cdot \begin{array}{c}
{[\mathrm{M}][\chi]^{n-1}} \\
(1+K[\mathrm{M}])^{n}
\end{array} \\
& {[\chi]=[\mathrm{C}]_{\text {total }}-\left[\mathrm{M}^{*}\right]}
\end{aligned}
$$

上記の諸式を用いて $k_{p}$ を計算する方法を 2.1 .3 の場 合について述べる。(7)式によって $[\mathrm{C}]_{\mathrm{total}} /[\mathrm{M} \cdot \mathrm{C}]$ と $1 /[\mathrm{M}]$ をプロットすると，得られた直線の勾配と切片からそれ ぞれ $\left(1 / K_{M}+K_{A}[\mathrm{~A}] / K_{M}\right)$ と $\left(k_{i} / k_{t}\right)\left(K_{A}[\mathrm{~A}] / K_{M}\right)+1$ が 得られる。これらの值を(8) 式に代入すると, 重合速度 $\left(R_{p}\right)$ を測定すれぱ $k_{p}$ が計算できる関係式を得る。ただ $L[M \cdot C]$ は $\pi$-complex $(M \cdot C)$ が紫外部に示す吸収の吸 光度より計算する。

\section{3. 実踰結果}

試料の脱水，精製および実験は前報と同様に行ない，
測定は特にことわらない限り $30^{\circ} \mathrm{C} て ゙$ 行なった。

\section{1 モノマー, 開始用間に存在する $\pi$-complex に ついて}

カチオン重合系において，モノマー(M) と開始剤 (C) はそれぞれ典型的な electron-donor および acceptor であり, 両者の間に charge transfer type の $\pi$-com. plex が存在することが予想される ${ }^{5)}$ 。イソオクタン中に おいて, 種々のアルキルビニルェーテルとヨウドの間に 存在する $\pi$-complex についてはすでに報告しだ)。し かし,この種の $\pi$-complex は広く一般にカチオン重合 系に存在する。

\subsection{1 スチレンおよび類似物質とヨウドとの間の $\pi-$ complex}

二塩化エチレン中において，スチレンまたはトルェン とヨウド間の $\pi$-complex の示寸紫外吸収スペクトルを Fig. 1 (a), (b) に示す。標準溶液として, 試料と同濃度の electron donor を含む溶液を用いた。これらの吸収が遊 離の $\operatorname{donor}(\mathrm{M}), \operatorname{acceptor}(\mathrm{C})$ と平衡関係にある $1: 1$ の $\pi$-complex によると仮定して遒いた Benesi-Hildebrand の式

$$
\frac{[\mathrm{C}]_{\mathrm{free}}}{d}=\frac{1}{K \cdot \varepsilon} \cdot \frac{1}{[\mathrm{M}]}+\frac{1}{\varepsilon}^{6)}
$$

に Fig. 1 の結果を用いて，Fig. 2 のプロットを得た。こ こで, $d, \varepsilon$ はそれぞれ $\pi$-complex に基く吸収の吸光度と モル吸光係数であり， $K$ は $\pi$-complex 生成の平衡定数 である。Fig. 2 のプロット(a)または (b) を得るにあたっ

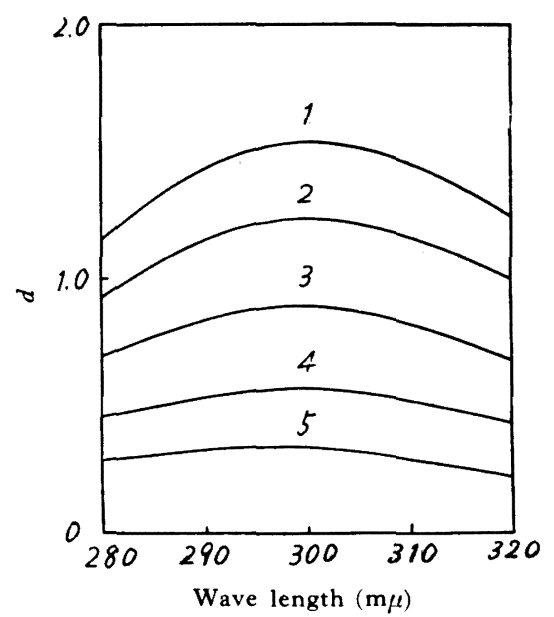

1: $\left[\right.$ toluene] $=0.984 \mathrm{~mol} / l, \quad\left[I_{2}\right]$ tota $]=1.46 \mathrm{~m} \mathrm{~mol} / l$.

$2:$ toluene] $=0.683 \mathrm{~mol} / l, \quad\left[I_{2}\right]$ total $=1.50 \mathrm{~m} \mathrm{~mol} / l$.

3: [toluene] $=0.430 \mathrm{~mol} / l, \quad\left[I_{2}\right]$ total $=1.61 \mathrm{~m} \mathrm{~mol} / l$.

4: $\left[\right.$ toluene] $=0.235 \mathrm{~mol} / l, \quad\left[I_{2}\right]$ total $=1.61 \mathrm{~m} \mathrm{~mol} / l$.

$5:$ [toluene] $=0.128 \mathrm{~mol} / l, \quad\left[\mathrm{I}_{2}\right]$ total $=1.61 \mathrm{~m} \mathrm{~mol} / l$.

Fig. 1. (a) Ultraviolet absorption spectra of tolueneiodine complex in ethylene chloride $\left(25^{\circ} \mathrm{C}\right)$. 


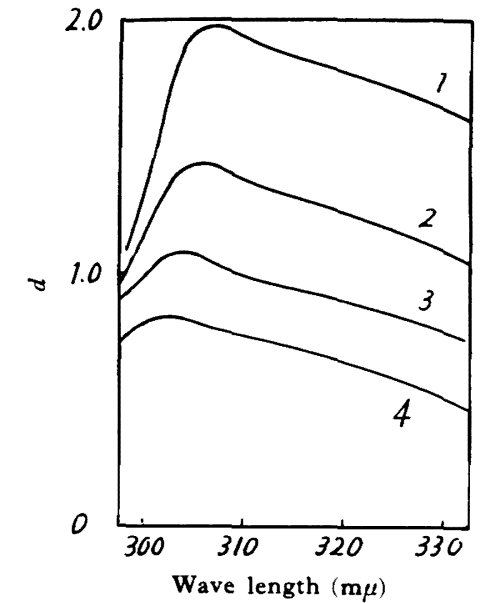

$1:[$ styrene $]=0.78 \mathrm{~mol} / l, \quad\left[\mathrm{I}_{2}\right]_{\mathrm{free}}=1.62 \mathrm{~m} \mathrm{~mol} / l$.

$2:$ [styrene] $=0.45 \mathrm{~mol} / l, \quad\left[\mathrm{I}_{2}\right]_{\text {free }}=1.67 \mathrm{~m} \mathrm{~mol} / l$.

$3:$ [styrene] $=0.28 \mathrm{~mol}_{i} l, \quad\left[\mathrm{I}_{2}\right] \mathrm{f} \mathrm{r} \in \mathrm{\theta}=1.75 \mathrm{~m} \mathrm{~mol} / l$.

$4:$ [styrene] $=0.17 \mathrm{~mol} / l,\left[I_{2}\right]$ free $=1.80 \mathrm{~m} \mathrm{~mol} / l$.

Fig. 1. (b) Ultraviolet absorption spectra of styreneiodine complex in ethylene chloride $\left(25^{\circ} \mathrm{C}\right)$.

て, 吸光度 $d$ として, それぞれ Fig. 1(a), (b) の吸收ピーク の值を用い，[M] はそれぞれに対応する electron donor の濃度を用いた。また $[\mathrm{C}]_{\mathrm{free}}$ はこの実験の場合, 遊離状 態にあるョウド䜘度に相当し, $500 \mathrm{~m} \mu$ 付近の遊離ヨウド の吸収の吸光度から計算した。Fig. 2 のプロットの切片 の逆数として $\varepsilon$ 值が, さらに勾配とあわせて $K$ 值を計算 することができる。

スチレンとヨウド，およびトルェンとヨウドとの complex はそれぞれ $K=1.18, K=0.62$ のごとく異な る平衡定数をもつが，そのも值はいずれもほぼ $2900 て ゙ ，$ 等しい値をもつことがわかった。このことは, 種々のス チレン誘導体とヨウドフ, 種々のベンゼン誘導体とヨウ $r^{8)}$ との complex の $\varepsilon$ 值は置換基によらずほぼ一定で ある事実とあわせて， $\varepsilon$ 值を測定できない complex の $\varepsilon$ 值を知るのに有効である。

\subsection{2 スチレンおよひその類似物兵と四塩化ススと の間の $\pi$-complex}

典型的なカチオン重合触媒である四塩化スズも，スチ レンおよびその類似物質と $\pi$-complex をつくる。その 二塩化エチレン中に扔引る柴外吸収スペクトルを Fig. 3 に示す。ただしこの場合も, 同嶩度の electron" donor 溶液を標準溶液とした。ヨウドを electron acceptor と した場合, $\left[\mathrm{I}_{2}\right]_{\text {free }}$ が定量できるため Benesi-Hildebrand 式を用いてスチレンまたはトルェンとの間につくる $\pi$ complex 生成の平衡定数とそのモル吸光係数を測定する ことができた。しかし四塩化スズを electron acceptor とした場合, $\left[\mathrm{SnCl}_{4}\right]_{\text {free }}$ は測定できず, また共存する他

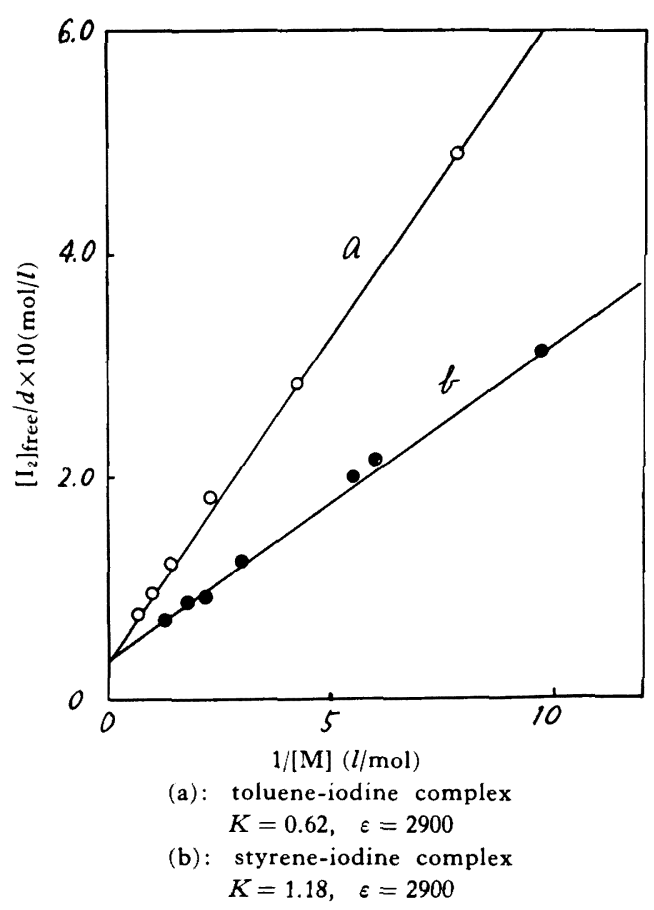

Fig. 2. Benesi-Hildebrand's plot.

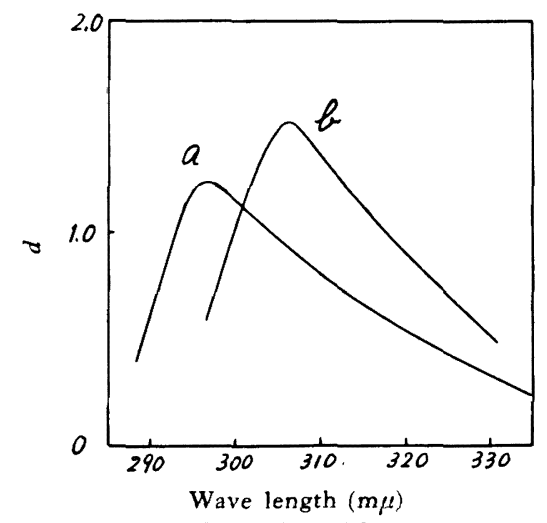

(a): [toluene] $=0.185 \mathrm{~mol} / l$,

$\left[\mathrm{SnCl}_{4}\right]$ total $=4.95 \times 10^{-2} \mathrm{~mol} / l$.

(b): [styrene] $=0.645 \mathrm{~mol} / l$,

$[\mathrm{SnCl}\}$ total $=2.5 \times 10^{-2} \mathrm{~mol} / l$.

Fig. 3. Ultraviolet absorption spectra of styrene, toluene- $\mathrm{SnCl}_{4}$ complex in ethylene chloride.

の electron donor $(\mathbf{A})$ (たとえば共存する水など) との $\pi$ complex 形成が無視できないため, Benesi-Hildebrand 式は次のごとく㹡張しなければならない。 


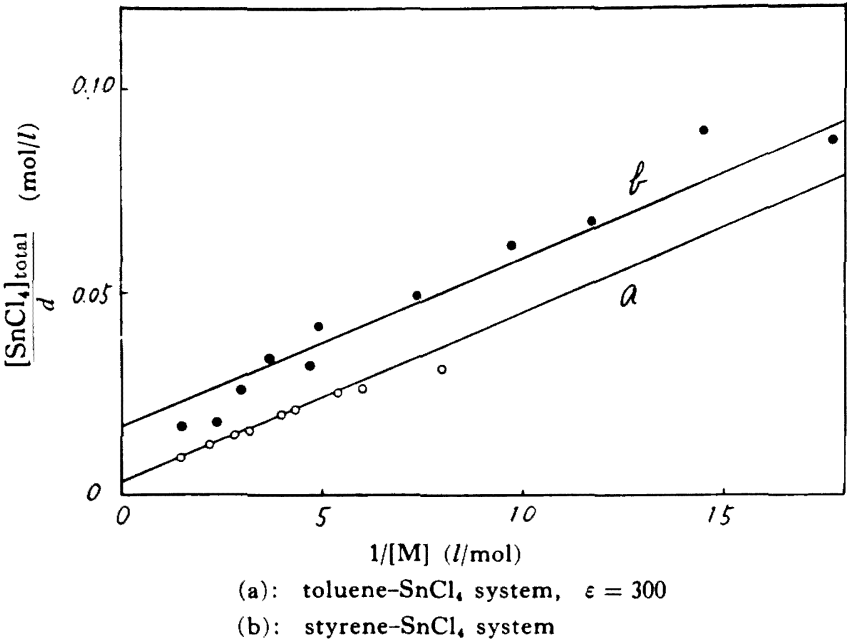

Fig. 4. The plot of $\left[\mathrm{SnCl}_{4}\right]_{\text {total }} / d$ against $1 /[\mathrm{M}]$.

$$
\begin{aligned}
\frac{[\mathrm{C}]_{\text {total }}}{d}= & \left(\frac{1}{K_{M} \cdot \varepsilon}+\frac{K_{A}[\mathrm{~A}]}{K_{M} \cdot \varepsilon}\right) \frac{1}{[\mathrm{M}]} \\
& +\frac{k_{i}}{k_{t}} \cdot \frac{K_{A}[\mathrm{~A}]}{K_{M} \cdot \varepsilon}+\frac{1}{\varepsilon}
\end{aligned}
$$

これは (7) 式の両辺ををで割ったものに他ならず，そ れぞれの付号の意味は前節 (2.1.3) において記したとお りである。

Fig. 3 に示した吸収の吸収ピークにおける吸光度 $d$ を スチレンまたはトルェン濃度を変えて測定し $\left[\mathrm{SnCl}_{4}\right]_{\text {total }}$ /d と $1 /[\mathrm{M}]$ をプロットすると直線関倸を得た(Fig. 4)。 図の直楾は最小 2 乘法によって求めた。トルエン一四塩 化スズ采では当然 $k_{i} / k_{t}=0$ でなければならず切片の逆 数は両者間の $\pi$-complex のモル吸光係数を示す。さら にこれを前項で述べたごとく、スチレンー四塩化スズ complex のモル吸光倸数であると近似的に考えることが できる。

この紫外吸収の吸收ピークにおける吸光度は, Fig. 5 に示すように四塩化スズ濃度に比例する。さらに, Fig.2, 4 に見られるように, これらの紫外部吸収のピークの吸 光度は，それぞれ Benesi-Hildebrand の式および (11) 式を満足する。これらの諸式はいずれも，これらの吸収 が $\mathrm{M}+\mathrm{C} \rightleftarrows \mathrm{M} \cdot \mathrm{C}$ なる平衡関倸にある $1: 1 の \pi$-complex (M·C) によるという仮定より導いたものである。した がって，カチオン重合采において，この種の $\pi$-complex が存在することはほほ確かめられたと考えられる。

\section{2 重合速度 $\left(R_{p}\right)$}

3.2.1 スチレンーヨウトーニ塩化エチレン系

重合率-時間曲線は Fig. 6 のようになり，かなりはっき りとした誘導期間が認められる。同様な実験を $30^{\circ} \mathrm{C} に$

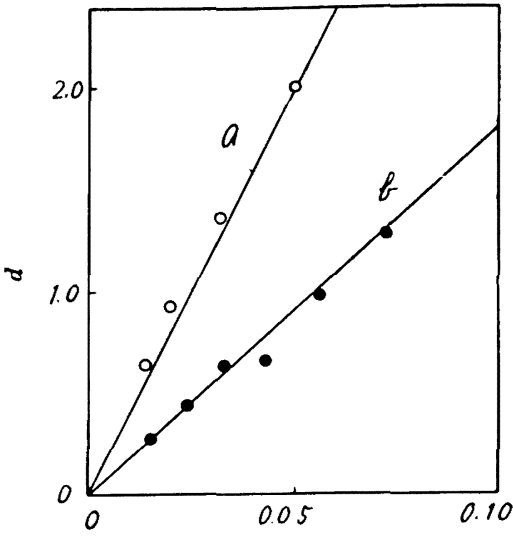

$\left[\mathrm{SnCl}_{4}\right](\mathrm{mol} / \mathrm{l})$

(a) $[$ toluene] $=0.22 \mathrm{~mol} / l$.

(b) [styrene] $=0.42 \mathrm{~mol} / l$.

Fig. 5. The plot of the optical density of $\pi$-complex against $\left[\mathrm{SnCl}_{4}\right]$ (in ethylene chloride).

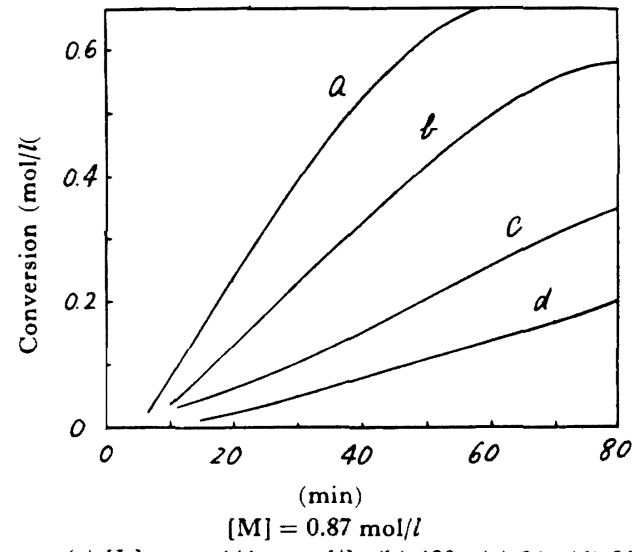

(a) $\left[I_{2}\right]$ total; $144 \mathrm{~m} \mathrm{~mol} / l$. (b) 120, (c) 96 , (d) 84

Fig. 6. Time-conversion curve (styrene-iodineethylene chloride system $20^{\circ} \mathrm{C}$ ).

おいて行ない, その重合率-時間曲線の直線部分の勾配か ら $R_{p}$ を求め，その結果を Fig. 7 (a), (b)にまとめた。ス チレンの誘電率 $\left(30^{\circ} \mathrm{C} て ゙ 2.4\right)$ は二塩化エチレンのそれ $\left(30^{\circ} \mathrm{C}\right.$ で 9.6) に比べて小さく，そのため，スチレン瀑度 がある程度增すと，重合系の誘電率を低下し，遂に $R_{p}$ の 減少をもたらすものと考えられる。両図より次の関係を 得た。

$$
R_{p}=k[\mathrm{M}]\left[\mathrm{I}_{2}\right]^{3} \quad([\mathrm{M}]<1 \mathrm{~mol} / l)
$$

この系のよらにヨウド濃度の大きい系ではヨウドの反 応次数が大きくなる効果はしばしば見受けられる ${ }^{9)} 。 R_{p}$ の実測值を Table 1 にまとめた。 


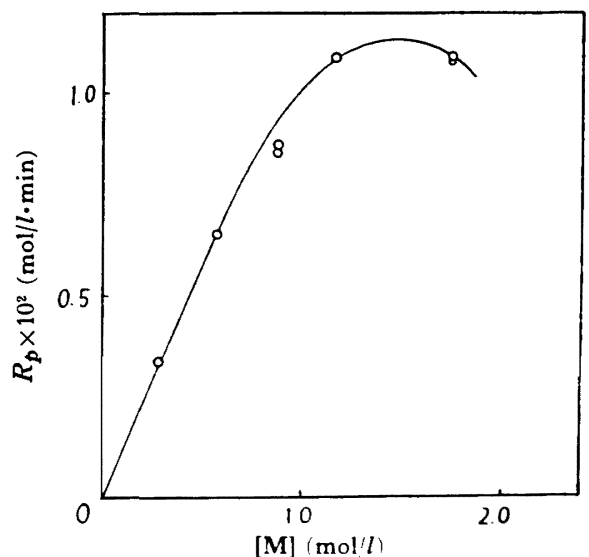

a) effect of $\left.[\mathrm{M}],\left[\mathrm{I}_{2}\right]_{\text {tots }}\right]=1.05 \times 10^{2} \mathrm{~m} \mathrm{~mol} / \mathrm{l}$.

Fig. 7. (a) Rate of polymerization $\left(30^{\circ} \mathrm{C}\right)$ (styrene-iodine-ethylene chloride).

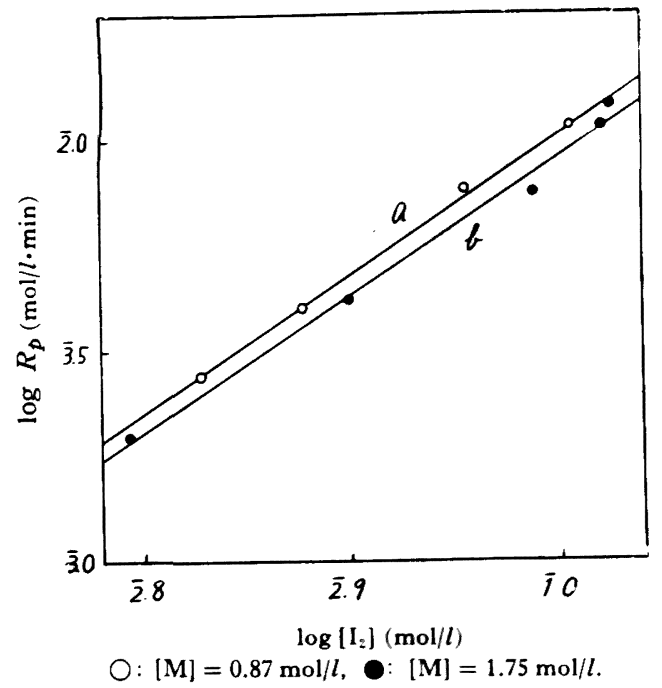

Fig. 7. (b) Effect of $\left[\mathrm{I}_{2}\right]_{\text {tutal }}$.

3.2.2 スチレン-四塩化スズ-二塩化エチレン系 この采の重合速度はほぼ次の関係で示される。

$$
R_{p}=k[\mathrm{M}]^{1.8}\left[\mathrm{SnCl}_{4}\right]
$$

われわれが以前実測した結果 ${ }^{10)}$ をわせて実験結果を Table 2 にまとめた。ただし, 重合速度は前項と同憡, 時 間-重合率曲線の最大勾配より求めたものである。

\section{$3.3 k_{p}$ の計算}

\subsection{1 スチレン-ヨゥド-二塩化エチレン系}

この系の重合開始反応はどのような機構をもっている かわからないが $R_{p} \curvearrowright\left[\mathrm{I}_{2}\right]^{3}$ の関倸から判断すると, 開始 反応におけるヨウドの反応次数 $(n)$ は 3 であると考えら

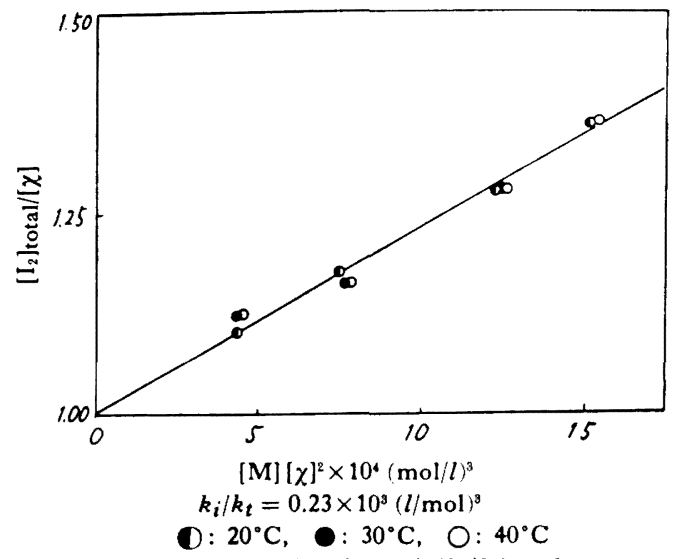

Fig. 8. Determination of $\left(\boldsymbol{k}_{\boldsymbol{i}} / \boldsymbol{k}_{\boldsymbol{t}}\right)$ values (styrene-iodine ethylene chloride system).

Table 1. Rate constant of propagation reaction $\left(k_{p}\right)$ (styrene-iodine-ethylene chloride system), $k_{i} / k_{t}=$ $0.23 \times 10^{3}\left(l / \mathrm{mol}^{3}\right)\left(30^{\circ} \mathrm{C}\right)$.

\begin{tabular}{|c|c|c|c|c|}
\hline$\underset{(\mathrm{mol} / l)}{[\mathrm{M}]}$ & $\begin{array}{l}{\left[\mathrm{I}_{2}\right]_{\text {rotal }}} \\
(\mathrm{mol} / l)\end{array}$ & $\begin{array}{c}R_{p} \\
(\mathrm{~mol} / l \cdot \min )\end{array}$ & $\begin{array}{c}k_{p} \\
(l / \mathrm{mol} \cdot \min )\end{array}$ & $\left.\left[\mathrm{M}^{*}\right] / \mathrm{I}_{2}\right]_{\text {total }}$ a) \\
\hline 1.75 & $1.06 \times 10^{-1}$ & 0.0118 & - & - \\
\hline 1.75 & 0.97 & 0.0075 & - & $\ldots$ \\
\hline 1.75 & 0.80 & 0.0044 & - & 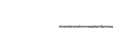 \\
\hline 1.75 & 0.62 & 0.0020 & - & - \\
\hline 1.75 & 1.05 & 0.0109 & - & - \\
\hline 1.16 & 1.05 & 0.0108 & 0.19 & 0.47 \\
\hline 0.87 & 1.05 & 0.0095 & 0.24 & 0.43 \\
\hline 0.58 & 1.05 & 0.0065 & 0.29 & 0.37 \\
\hline 0.29 & 1.05 & 0.0034 & 0.37 & 0.30 \\
\hline 0.87 & 1.01 & 0.0109 & 0.30 & 0.42 \\
\hline 0.87 & 0.90 & 0.0077 & 0.26 & 0.38 \\
\hline 0.87 & 0.75 & 0.0036 & 0.16 & 0.33 \\
\hline 0.87 & 0.68 & 0.0028 & 0.15 & 0.31 \\
\hline
\end{tabular}

a) $\left[\mathrm{M}^{*}\right]$ was calculated by using equations $(12-\mathrm{a})$ and (12-b), putting $k_{i} / k_{t}=0.23 \times 10^{3}$ and respective $\left[I_{2}\right]_{\text {total }}{ }^{-}$, (M] values into them. $\left[\mathrm{M}^{*}\right] /\left[\mathrm{I}_{2}\right]_{\text {total-value }}$ is the ratio of the concentration of the active end in stationary state to the total concentration of the initiator.

れる。また、この系ではスチレン、ヨウド間の相互作用 は弱く complex を形成したヨウドと遊離のヨウドとを 区別する必要はないと考えられる。換言すれば [M.C] =0であるといえる。したがって $(9)$ 式は

$$
\begin{gathered}
\frac{\left[\mathrm{I}_{2}\right]_{\text {total }}}{[\chi]}=1+{ }_{k_{\ell}}^{k_{i}}[\mathrm{M}][\chi]^{2} \\
{[\chi]=\left[\mathrm{I}_{2}\right]_{\text {total }}-\left[\mathrm{M}^{*}\right]}
\end{gathered}
$$




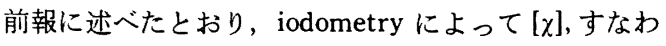
ち, チオ硫酸ソーダを酸化する能力を有しているヨウド

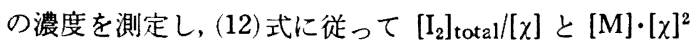
をプロットし(Fig. 8), その勾配より $k_{i} / k_{t}$ 值を得た。前 報に述べたごとく $R_{p}$ の測定結果とあわせて $k_{p}$ を計算 することができる。結果を Table 1 にまとめた。

\subsection{2 スチレン-四塩化スズ-二塩化エチレン系}

3.1.1 で述べたごとく二塩化ェチレン中のスチレン四塩化スズ complex の紫外吸収の $\varepsilon$ 值は同じ溶媒中の, トルェン-四塩化スズ complex のそれ $(\varepsilon=300)$ で近似 することができる。

Plesch がこの系に与えだ機構に従って導いた (7) 式に 従って $\left[\mathrm{SnCl}_{4}\right]_{\text {total }} /\left[\right.$ styrene $\left.\cdot \mathrm{SnCl}_{4}\right]$ と $1 /[$ styrene] のプ ロットを行ない，その勾配と切片からそれぞれ

$$
\begin{gathered}
\alpha=K_{M}^{1}+\frac{K_{A}[\mathrm{~A}]}{K_{M}}=1.23 \\
\hat{\beta}+1=\begin{array}{c}
k_{i} \\
k_{t}
\end{array} \frac{K_{A}[\mathrm{~A}]}{K_{M}}+1=5.10
\end{gathered}
$$

を得た。これは Fig. 4 (a) の勾配，切片のそれぞれに $\varepsilon=300$ を乗じたものにほかならない。一方 (8) 式より

$$
R_{p}=\frac{k_{p} \cdot \hat{\beta} \cdot[\mathrm{M}]\left[\mathrm{SnCl}_{4}\right]_{\text {total }}}{\frac{\alpha}{[\mathrm{M}]}+\beta+1}
$$

ここにおいて $k_{p}$ を除いてすべて既知もしくは測定可能 な值であるから $R_{p}$ を測定すれば $k_{p}$ を計算することが できる。重合速度の測定結果とあわせて $k_{p}$ の計算値を Table 2 にまとめた。

\section{4. 考察}

\begin{tabular}{|c|c|c|c|c|}
\hline $\begin{array}{l}{[\mathrm{M}]} \\
(\mathrm{mol} / l)\end{array}$ & $\begin{array}{c}{\left[\mathrm{SnCl}_{4}\right]_{\text {total }}} \\
(\mathrm{mol} / l)\end{array}$ & $\begin{array}{c}R_{p} \\
(\mathrm{~mol} / l \cdot \min )\end{array}$ & $\begin{array}{c}k_{p} \\
(l / \mathrm{mol} \cdot \\
\min )\end{array}$ & {$\left[\mathrm{M}^{*}\right] / /$} \\
\hline 1.75 & $3.06 \times 10^{-3}$ & 0.102 & 27.0 & 0.71 \\
\hline 1.46 & 3.26 & 0.077 & 23.0 & 0.69 \\
\hline 1.09 & 3.06 & 0.058 & 26.6 & 0.66 \\
\hline 0.88 & 3.06 & 0.044 & 26.0 & 0.63 \\
\hline 0.55 & 3.20 & 0.023 & 23.4 & 0.56 \\
\hline $1.72^{\mathrm{a})}$ & $2.95 \times 10^{-8 a)}$ & $0.070^{\mathrm{a})}$ & 19.7 & 0.71 \\
\hline $1.72^{\mathrm{a})}$ & 4.31 & $0.105^{a)}$ & 20.3 & 0.71 \\
\hline $1.72^{\mathrm{a})}$ & 5.79 & $0.135^{a)}$ & 19.2 & 0.71 \\
\hline
\end{tabular}

カチオン重合ではラジカル重合と異なり, 重合素反応

Table 2. Rate constant of propagation reaction $\left(k_{p}\right)$ (styrene- $\mathrm{SnCl}_{4}$-ethylene chloride system) $\left(30^{\circ} \mathrm{C}\right)$.

a) These values were noted from the previous paper ${ }^{10)}$. $k_{p}$ and $\left[\mathrm{M}^{*}\right] /\left[\mathrm{SnCl}_{4}\right]_{\text {total }}$ were calculated using these results, by the method reported in this paper.
の速度定数を求める手段が確かめられていない。そして, このことが，カチオン重合の素反応について具体的な検 討がすすめられていない原因の一つであろうと思われ る。上記の目的にそって, 素反応の反応速度定数を求め ることによって, 反応機構を検討するためには, 重台系 として最も簡単であり, 実験結果の再現性に富む系を選 ふ必要がある。第 1 報，第 2 報においてヨウドを開始剂 とするスチレン誘導体および種々のアルキルビニルエー テルの, カチオン重合の生長反応の速度定数を測定する 方法について述べた。本報告ではさらに, 代表的なカチ オン重合触媒である四塩化スズによるスチレンのカチオ ン重合における $k_{p}$ の測定法をあわせて述へた。以上の 方法はいずれも, 重合活性末端に関して定常状態がなり たっていると考えられる系に，ほぼ一般的に適用できる ものであり，生長反応の機構をその速度定数より論ずる ことが可能になったと考えられる。

カチオン重合の生長反応は温度を一定とした場合, モ ノマー, カルボニウムイオン, 溶媒, 対アニオンによっ て規定されると考えられる。前 3 者についてはすでに報 告した。

本報告の結果によると，二塩化ェチレン中でスチレン を重合するとき，ヨウドを開始剤とした場合 $k_{p} \cong 0.22$ $(l / \mathrm{mol} \cdot \mathrm{min})$ であり, 四塩化スズを開始剤とした場合 $k_{p} \cong 25.2(l / \mathrm{mol} \cdot \mathrm{min})$ である。この差は, それぞれの開 始剤から生した対アニオンの違いに帰するほかはなく, 強、 Lewis acid から生じた対アニオンほど生長反応を 促すことが結論できる。

Plesch $^{\text {3a) }}$ と Pepper ${ }^{\text {sb) }}$ はいずれも二塩化ェチレンを 溶媒としてスチレンを重合した場合, それぞれ, 四塩化于 タンを開始剂として $k_{p}=3.6 \times 10^{2}(l / \mathrm{mol} \cdot \mathrm{min})$, 硫酸を 開始剂として $k_{p}=1.4 \times 10^{2}(\mathrm{l} / \mathrm{mol} \cdot \mathrm{min})$ を得た。ただ し前者は, $\left[\mathrm{M}^{*}\right]=\left[\mathrm{TiCl}_{4}\right]_{\text {total }}$ を仮定し, 後者は $\left[\mathrm{M}^{*}\right]$ に 関して非定常状態を仮定して求めたもので，いずれも $25^{\circ} \mathrm{C}$ におけるものである。Plesch はこれら二つの值を 比較して, $k_{p}$ は対アニオンの性質にそれほど敏感でない のだろうと述べている。しかし前者の場合当然 $\left[\mathrm{M}^{*}\right]<$ $\left[\mathrm{TiCl}_{4}\right]_{\text {total }}$ でなければならず, したがって四塩化チタン 触媒に対応する $k_{p}$ 值はさらに大きいものでなければな らない。さらに，われわれがヨウドおよび四塩化スズを 開始凨として同じ采で求めた $k_{p}$ 値を比較すると, 生長 反応速度定数 $k_{p}$ は, 対アニオンによって, むしろ著し い影響を受けるこ考えるのが妥当と考えられる。

われわれは，定常状態における均一カチオン重合の生 長反応の速度定数を求める方法を確かめた。その結果, 生長反応はカルボニウムイオン，モノマーのみならず, ラジカル重合と異なり，対アニオンおよび溶媒に著しい 影響を受けることがわかった。 


\section{文献}

1) S. Okamura, N. Kanoh and T. Higashimura : Makromol. Chem., 47, 19(1961)

2) S. Okamura, N. Kanoh and T. Higashimura : ibid., 47, 35 (1961)

3) a) W. R. Longworth and P. H. Plesch : IUPACsymposium über Makromoleküle 1959 in Wiesbaden III A 11.

b) M. J. Hayes and D. C. Pepper : Proc. Chem. Soc. [London] 1958, Aug., 228.

c) F. J. Welch: J. Am. Chem. Soc., 81, 1345 (1959)
4) 東村敏延, 加納夏樹, 米沢貞次郎, 福井謙一, 岡村 誠三：日化，81，550(1960)

5) R. S. Mulliken: J. Am. Chem. Soc., 74, 811 (1952) ; R. S. Mulliken: J. Phys. Chem., 56, $801(1952)$

6) H. A. Benesi and J. H. Hildebrand: J. Am. Chem. Soc., 71, 2703(1949)

7) 加納夏樹, 東村敏延, 岡村誠三：未発表

8) R. S. Mulliken: J. Am. Chem. Soc., 72, 600 (1950)

9) A. G. Evans, P. M. S. Jones and J. H. Thomas: J. Chem. Soc., [London] 1957, 2095

10) 岡村誠三, 東村敏延：高化，13，262(1956)

\title{
Rate Constant of the Propagation Reaction in Stationary State of Cationic Polymerization
}

\author{
III. Polymerization of Styrene Catalyzed by Stannic Chloride
}

By Natsuki Kanoh*, Toshinobu Higashimura* and Seizo Okamura*

A principle was proposed for the method to obtain rate constant $\left(k_{p}\right)$ of propagation reaction of cationic polymerization in stationary state. This method is based on the spectroscopic measurement of concentration of - --complex formed from monomer and catalyst, Lewis acid. By this and previously reported methods,$+ 25.2(l / \mathrm{mol} \cdot \mathrm{min})$ and $0.22(l / \mathrm{mol} \cdot \mathrm{min})$ were obtained as $k_{p}$-values on styrene-stannic chloride-ethylene chloride and styrene-iodine-ethylene chloride systems respectively. From these results it was concluded that the $k_{p}$-value becomes larger when the stronger Lewis acid is used.

† S. Okamura, N. Kanoh and T. Higashimura: Makromol. Chem., 47, 19 (1961)

\footnotetext{
* Department of Polymer Chemistry, Faculty of Engineering, Kyoto University, (Kyoto,)
} 